\title{
Ethnobotanical survey of plants used in Afyonkarahisar-Turkey
}

\author{
Süleyman Arı $^{1}$, Mehmet Temel ${ }^{1}$, Mustafa Kargıoğlu ${ }^{1}$ and Muhsin Konuk ${ }^{2^{*}}$ (D)
}

\begin{abstract}
Background: The traditional knowledge about plants and their uses in Turkey is disappearing in recent years because the new generations of villagers migrate to big cities for a better life. Afyonkarahisar located at the intersection of roads and phytogeographical regions (Mediterranean, Iran-Turan, and Euro-Siberian) has more than 2500 plant species. This richness of plant diversity promotes the indigenous commuity for the traditional use of wild plants. The aim of the study is to show wild plants' ethnobotanical usages associated with medicinal, food, fodder, and household goods in 31 settlements within the boundaries of Afyonkarahisar province.

Methods: The ethnobotanical data were collected from 46 informants by means of semi-structured interviews from 2012 to 2014. Ethnobotanical uses of plants of the study area were conducted in the vicinity of Afyonkarahisar (5 districts, 8 towns, 15 villages, and 3 neighborhood centers).

Results: One hundred and thirty plant taxa belonging to 39 families were recorded and collected. Hundred and seventy-eight different uses of these plants were documented and used generally for medicinal (84), food (68), fodder (16), household goods (3), dyes (3), handicrafts (3) and religious (1).

Conclusion: This study provides interesting uses of plants in the local community of Afyonkarahisar and its surrounding area, in what purpose they make use of plants, how they make use of them and obtained results will contribute to economy of villagers. Since the local people, especially in villages, are poor and do not have health care, they use the plants to treat illnesses, food, fodder, household goods and other uses (evil eye). Also this study will light the way for posterity for next generations.
\end{abstract}

Keywords: Afyonkarahisar, Ethnobotany, Food plants, Medicinal plants

\section{Background}

People have interacted with plants since ancient times. This interaction has contributed to flourishing of scientific fields such as ethnobotany and paleoethnobotany [1]. Ethnobotanical studies began in the early 1800s when John W. Harsberger, a famous botanist, proposed ethnobotanical study for the first time [2]. The scope of plant use has changed since the 1800 s to this day. The frequency and purpose of use of plants by people vary in regard to social, cultural, and economic needs. Plants are used for purposes of food, medicine, fuel, industry, ornament, and effects. Purposes of use also vary in regard to people's priority of needs [1, 3-9]. Turkey, with more than 11,000 taxa is a flora-rich country due to its

\footnotetext{
* Correspondence: mkonuk@gmail.com

${ }^{2}$ Department of Molecular Biology and Genetics, Faculty of Engineering and Natural Sciences, Üsküdar University, 34662 Istanbul, Turkey

Full list of author information is available at the end of the article
}

climate and phytogeographical positions (Mediterranean, Iran-Turan, and Euro-Siberian) is a significant position as being a flora-rich country. The endemic plants in its flora occupy $1 / 3$ of total taxa. Anatolian people have been using these plants as food and medicine since Paleolithic times [10, 11]. Approximately 1000 taxa are used for medicinal purposes and 350 plant species are used in internal and external trade [12]. Afyonkarahisar is located where the three regions intersect. This makes Afyonkarahisar a flora rich region, people use the plants arund their environment for different purposes.

Turkish people living in rural areas use especially wild plants. Generally, the usage of plants are for food and medical purposes. In recent years, traditional ethnobotanical knowledge and prevalence of medicinal plants have been investigated by researchers in different areas of Turkey [13-41]. As a results of these studies a great 
increase on the level of traditional knowledge of plants occured. On the other hand, more detailed studies are needed to focus region by region. Therefore this study was carried out to extend Afyonkarahisar's ethnobotanical knowledge due to a limited ethnobotanical studies [42-46] conducted in the near region; living in suburbs and in villages; protecting and maintaining their traditional culture and customs and rich uses of plants by local people. The aims of this study were: (1) to determine the local and scientific names of the plants, (2) to document and analyse the traditional ethnobotanical knowledge herited by local people living in Afyonkarahisar and its surrounding area.

\section{Methods}

\section{Study Area}

Afyonkarahisar is $1034 \mathrm{~m}$ above sea level. It is located $38^{\circ}$ $45^{\circ} \mathrm{N}$ latitude and $30^{\circ} 32^{\prime} \mathrm{E}$ longitude. The total area of Afyonkarahisar is $14,295 \mathrm{~km}^{2}$ and it occupies $1.8 \%$ of Turkey's land. In north of Eskişehir, northwest of Kütahya, east of Konya, south of Isparta, west of Ușak, southwest of Denizli and Burdur are located (Fig. 1) [46]. Despite the fact that Afyonkarahisar is located in the Aegean region, its climate is similar to that of the central Anatolia region. Winters are cold and tough with intense snow, summers are hot and dry, and spring and autumn months feature rain. Precipitation is raining in spring and autumn [47]. According to Erinç [48], the index value of Afyonkarahisar is $23.9 \mathrm{~lm}$. In the vegetation of Afyonkarahisar, cedar and blackpine are found along with various species including relict ones. However, blackpine forests, the dominant factor of forest formation, have been significantly destroyed and oak groups have replaced them. The destruction is greater especially in fields around settlements, and these fields have turned into anthropogenic steppe [47]. The main livelihoods of the local community in the research area are tree felling, sheep and cattle husbandry, and agriculture. Animal husbandry consists of small numbers of cattle per household (average one), kept for meat and milk, with dairy products being sold in local bazaars. Since the area consists largely of forested hillsides, crop production is restricted to small fields, and annual incomes from agriculture are therefore relatively low. Monthly incomes are in the region of US \$230-350 for workers and shepherds, and $\$ 350$ for agricultural workers in those months that they work. On average, $50 \%$ of the population is young (under 30 years), $30 \%$ are middle-aged (30-50 years), and $20 \%$ are old (50+ years). Although $80 \%$ of the middle-aged and nearly $80 \%$ of the older generation is not literate, almost all young people are literate.

\section{Data collection}

Specimens were collected by the authors in Afyonkarahisar and its surrounding area in the years between 2012 and
2014. Thirty-one settlements were visited for field research. Two hundred people were contacted, and 46 of them accepted to become our informants who have ethnobotanical experience. Thirty-five of them were male and 11 of them were female. Data were collected from nine informants between the ages of 35 and 50, 17 informants between the ages of 50-65, and 20 informants over the age of 65. Interviews with the men were usually carried out in the teahouses where they come together, and with women in their homes, bazaars and gardens. A questionnaire was administered to the informants through face-to-face interviews. Information that had been carried to the region from the outside and that was not used or confirmed were not included and recorded. During the interviews, the below questions were asked to the participants.

(1) Name and surname

(2)Age and sex

(3)Educational level

(4) Are plants collected in your region?

(5)Do you have any contact with plants?

(6)Can you show the plants you use in your region?

(7) Can you tell the local names of the plants you use in your region?

(8)In which season do you collect the plants you use in your region?

(9) When collecting plant, which parts of the plant do you collect and how do you collect them?

(10) Which parts of the plants do you use? (Flower, fruit, leaves, root, tuber, young shoots, branch, galbula, cupula, stem, above ground parts etc.).

(11) How do you prepare and administrate the plants' parts?

Answers given above questions with doubt were not recorded. Specimens were collected and identified by the authors according to Davis [49] and the studies related to the flora Afyonkarahisar by Kargıoglu et al. [44, 45]. Plants were photographed as well as being observed in the research field. Voucher specimens are saved in the Herbarium of Afyon Kocatepe University (AKUH). Herbarium numbers of the plant taxa were given in Table 1.

\section{Results and discussion}

As seen in Table 1 and Fig. 2, the number of plant taxa used by the indeginous community of Afyonkarahisar and the surrounding area is 130 that belong to 93 genera and 39 families, and a total of 178 ethnobotanical uses (remedies) were recorded. Medicinal use occupies the first place with 84 types of use. The others are food with 68 , fodder with 16 , handicrafts, painting and effects with three types of use each, and other (evil eye) with one. According to results, the percentage of species in 


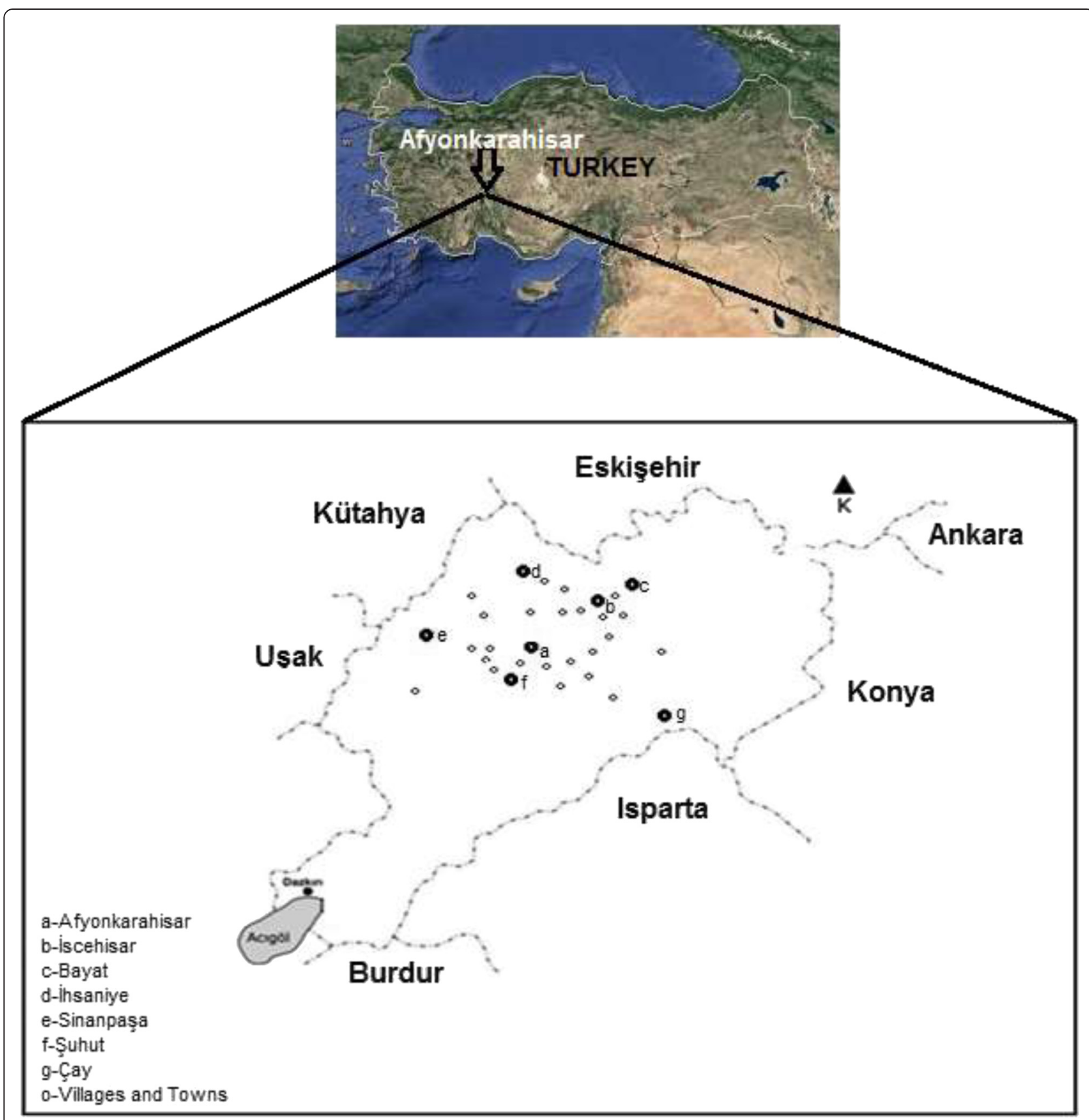

Fig. 1 The study area and Afyonkarahisar's location map

families are Asteraceae (14\%), Lamiaceae (10\%), Rosaceae (8 \%), Caryophyllaceae (5\%), Chenopodiaceae (5\%), Polygonaceae (5\%), Boraginaceae (4\%), Brassicaceae (4\%), Fabaceae (4\%), and $41 \%$ of them are composed of other subgroups. The richest subgroup rate in terms of frequency of ethnobotanical uses is $15 \%$ Asteraceae, followed by $10 \%$ Lamiaceae, $9 \%$ Rosaceae, $4 \%$ Brassicaceae, $4 \%$ Caryophyllaceae, 4 \% Chenopodiaceae, 4 \% Fabaceae, $3 \%$ Boraginaceae, and $42 \%$ other subgroups. The richest genus in terms of ethnobotanically significant is Rumex L. with 5 taxa, followed by Quercus L. with 4 taxa. Seven other 7 genera share thirt place with three taxa each. When we compare the studies of other reseachers [5, 7, 30, 35, 38, 41], the families of Asteraceae, Lamiaceae, Rosaceae are the most common families. But in the study of Doğan [11] the usage order of the families was a bit different than our findings. He reported that the highest number of taxa is similarly Asteraceae, but others were as Boraginaceae, Apiaceae, Lamiaceae, Caryophyllaceae and Geraniaceae. Rumex and Erodium are the most represented genera. 
Table 1 List of plants used as foodstuff or medicinal purposes in Afyonkarahisar (Inner-West Anatolia)

\begin{tabular}{|c|c|c|c|c|c|}
\hline Species & Plant Family & Local Name & Parts Used & Uses & Preparation and Administration \\
\hline Acanthus hirsutus Boiss. (AKUH 7506) & Acanthaceae & Ayıpençesi & Stem, Leaf & Fodder & Stem and leaf are consumed by animals for fodder. \\
\hline Amaranthus retroflexus L. (AKUH 7509) & Amaranthaceae & $\begin{array}{l}\text { Paşa pancarı, } \\
\text { kızlbacak }\end{array}$ & Leaf & Food & The plant's leaves are fried in oil and consumed. \\
\hline Conium maculatum L. (AKUH 7520) & Apiaceae & $\begin{array}{l}\text { Yılan kamışı, } \\
\text { gumarcık ot }\end{array}$ & Flower & Infection & $\begin{array}{l}\text { The plant oil were removed and the stem is driven to kill } \\
\text { germs in the stem structure. }\end{array}$ \\
\hline $\begin{array}{l}\text { Eryngium campestre L. var. virens Link. } \\
\text { (AKUH 7528) }\end{array}$ & & Çakırdikeni & Stem & Infection & Infusion as tea. \\
\hline $\begin{array}{l}\text { Arum elongatum Steven subsp. } \\
\text { elongatum Steven (AKUH 7542) }\end{array}$ & Araceae & Basur otu & Root, Tuber & Hemorrhoid & $\begin{array}{l}\text { Plant tuber part turned into powder by in effect simulating the } \\
\text { board. The capsule was consumed. }\end{array}$ \\
\hline $\begin{array}{l}\text { Dracunculus vulgaris Schoot. (AKUH } \\
\text { 7564) }\end{array}$ & & Yılan bıçağı & Leaf & Infection & The leaf part is used as a salve on a wound. \\
\hline Muscari comosum (L.) Mill. (AKUH 7597) & Asparagaceae & $\begin{array}{l}\text { Dağ soğanı, } \\
\text { ada soğanı }\end{array}$ & $\begin{array}{l}\text { Above ground } \\
\text { parts }\end{array}$ & Circulatory system & Infusion as tea. \\
\hline $\begin{array}{l}\text { Tragopogon latifolius Boiss. var. } \\
\text { angustifolius Boiss. (AKUH 7514) }\end{array}$ & Asteraceae & $\begin{array}{l}\text { Tekesakalı, } \\
\text { yemlik }\end{array}$ & Leaf & Stomach disease & The leaves are directly consumed. \\
\hline Helianthus tuberosus L. (AKUH 7521) & & Yerelması & Root, Stem & Food & Root and stem parts are directly consumed. \\
\hline $\begin{array}{l}\text { Anthemis tinctoria L. var. tinctoria L. } \\
\text { (AKUH 7545) }\end{array}$ & & Papatya & Flower & Respiratory system & Infusion as tea. \\
\hline $\begin{array}{l}\text { Hieracium pannosum Boiss. (AKUH } \\
\text { 7548) }\end{array}$ & & Sakız otu & Root & Oral and dental health & $\begin{array}{l}\text { The root of the plant is suspended in the sun, the resulting } \\
\text { liquid such as milk dry up like chewing gum is for chewing. }\end{array}$ \\
\hline $\begin{array}{l}\text { Anthemis wallii Hub.-Mor. et Reese } \\
\text { (AKUH 7501) }\end{array}$ & & Papatya & Flower & Asthma and shortness of breath & Infusion as tea. \\
\hline $\begin{array}{l}\text { Chondrilla juncea L. var. juncea. (AKUH } \\
\text { 7504) }\end{array}$ & & $\begin{array}{l}\text { Karakavuk, } \\
\text { çıtlık, çengel } \\
\text { sakızı }\end{array}$ & Leaf & Painkiller and stomach disease & The leaves are used in salad. \\
\hline Lactuca serriola L. (AKUH 7502) & & $\begin{array}{l}\text { Tarla marul, acı } \\
\text { marul, dilli tura }\end{array}$ & Leaf & Diet and attenuator & The leaves of the plant are consumed as part of a salad. \\
\hline $\begin{array}{l}\text { Achillea millefolium L. subsp. millefolium. } \\
\text { (AKUH 7534) }\end{array}$ & & Ayva denesi & Leaf, Flower & Diseases of the digestive system & Infusion as tea. \\
\hline Achillea teretifolia Willd. (AKUH 7532) & & Yaraotu & $\begin{array}{l}\text { Above ground } \\
\text { parts }\end{array}$ & Diseases of the digestive, skin and acne & $\begin{array}{l}\text { The plant's above ground parts boiled water by putting a } \\
\text { quantity of } 15 \mathrm{~min} \text { is suspended. Tea mixed with oil is } \\
\text { applied on acne and wounded regions. }\end{array}$ \\
\hline $\begin{array}{l}\text { Centaurea depressa M. Bieb. (AKUH } \\
\text { 7560) }\end{array}$ & & Gökbaş & Leaf & Food & The leaves of the plant are consumed by making a taco. \\
\hline Cichorium intybus L. (AKUH 7557) & & $\begin{array}{l}\text { Acı günek, } \\
\text { çiftlik otu }\end{array}$ & Leaf & Painkiller and stomach diseases & The plant's leaves are made of salad and rolls. \\
\hline Scolymus hispanicus L. (AKUH 7503) & & Diken & Stem & Digestive diseases & $\begin{array}{l}\text { The fleshy parts of the stem of the plant is consumed } \\
\text { directly in the blister pack }\end{array}$ \\
\hline Bellis perennis L. (AKUH 7511) & & Çayır papatyası & Flower & Medical, respiratory diseases & $\begin{array}{l}\text { Flower of the plant is dried, boiled water for } 3-5 \text { min by } \\
\text { joining strength, juice drink. }\end{array}$ \\
\hline
\end{tabular}


Table 1 List of plants used as foodstuff or medicinal purposes in Afyonkarahisar (Inner-West Anatolia) (Continued)

Doronicum orientale Hoffm. (AKUH 7513)

Onopordum anatolicum (Boiss.) Eig. (AKUH 7562)

Gundelia tournefortii L. var. tournefortii (AKUH 7556)

Artemisia campestris L. (AKUH 7589)

Achillea biebersteinii Afan. (AKUH 7573)

Inula anatolica Boiss.(AKUH 7576)

Berberis crataegina DC.(AKUH 7629)

Berberidaceae

Anchusa leptophylla Roemer \& Schultes Boraginaceae subsp. leptophylla (AKUH 7505)

Cerinthe minor L. subsp. auriculata (Ten.) Domac (AKUH 7558)

Anchusa undulata L. subsp. hybrida

(Ten.) Coutinho (AKUH 7552)

Alkanna tinctoria (L.) Tausch subsp. glandulosa Hub.-Mor. (AKUH 7561)

Anchusa azurea Mill. var. azurea. (AKUH 7553)

Alyssum desertorum Stapf. var. desertorum Stapf. (AKUH 7554)

Sisymbrium altissimum L. (AKUH 7590)

Barbarea sp. (AKUH 7583)

Capsella bursa-pastoris (L.) Medik. (AKUH 7507)

Sinapis arvensis L. (AKUH 7508)

Silene dichotoma Ehrh. subsp. dichotoma Ehrh. (AKUH 7512)

Stellaria media (L.) Vill. subsp. media. (AKUH 7510)

Silene vulgaris (Moench) Garcke var. vulgaris (AKUH 7515)

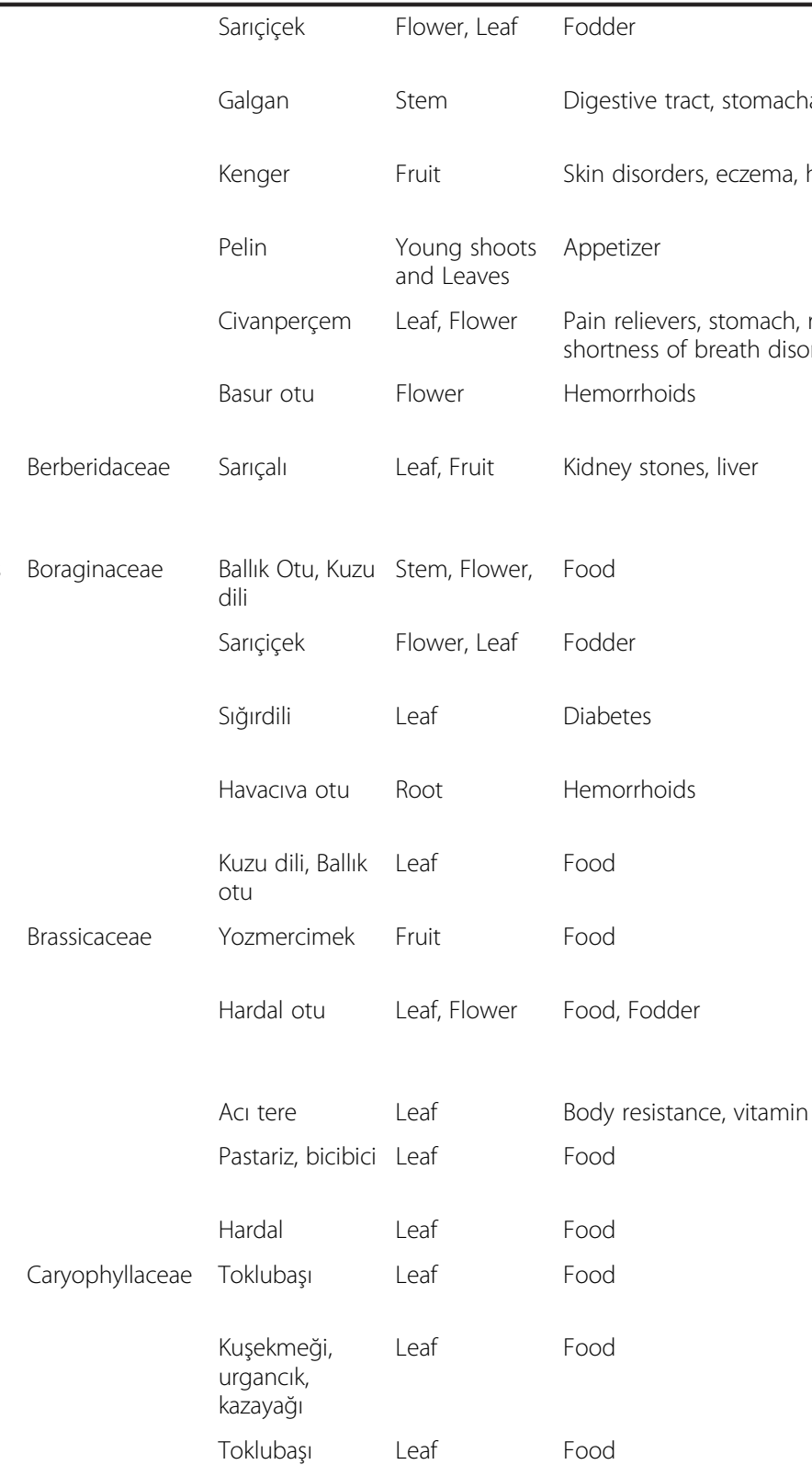

The plant flowers and leaves parts exposed to animals as bait.

The meaty parts in the stem of the plant is removed, directly from the defeated are consumed. Decoction as tea.

After roasting, the fruit portion is consumed.

Decoction as tea.

\section{Decoction as tea.}

Flower is boiled in water. It is used as a treatment for hemorrhoids district.

Leaves are effective for preventing kidney stones when they are consumed 15-20 days as salad. The fruit of the plant part (grape) is consumed directly.

Stem and flowers are put into the dough.

Leaves and flower parts are exposed to animals.

The plant's leaves are boiled and are consumed by joining into the dough.

Decoction as tea, the region also has a therapeutic equivalent of hemorrhoids.

Fresh leaves of the plant are boiled and put into dough.

Consumed directly by shepherds.

Leaf of the plant parts consumed in the form of rolls wrapped in phyllo dough. Leaves and flowers of the plant are given to animals.

The plant's leaves are made of salad.

The plant fresh leaves are consumed in the form of pastry wrapped into rolls.

Boiled fresh leaves is consumed in taco.

The plant's leaves are made of salad

The leaves of the plant is consumed wrapped in dough

Fried in oil and consumed. 
Table 1 List of plants used as foodstuff or medicinal purposes in Afyonkarahisar (Inner-West Anatolia) (Continued)

Agrostemma githago L. (AKUH 7628)

Dianthus zonatus Fenzl. var. aristatus (Boiss.) Reeve (AKUH 7620)

Dianthus zonatus Fenzl var. zonatus (AKUH 7598)

Vaccaria pyramidata Medik. var.

grandiflora (Fisch. ex DC.) Cullen (AKUH

7623)

Chenopodium album L. (AKUH 7588)

Chenopodium album L. subsp. album var. album (AKUH 7582)

Chenopodium foliosum (Moench) Asch. (AKUH 7630)

Beta trigyna Waldst. \& Kit. (AKUH 7625)

Kochia scoparia (L.) Schrad. (AKUH

7626)

Atriplex sp. (AKUH 7627)

Cistus laurifolius L. (AKUH 7624)

Juniperus oxycedrus L. subsp. oxycedrus (AKUH 7622)

Juniperus excelsa M. Bieb. (AKUH 7621)

Juniperus foetidissima Willd. (AKUH

7619)

Equisetum ramosissimum Desf. (AKUH

7617)

Euphorbia macroclada (Boiss.) (AKUH 7616)

Vicia cracca L. subsp. stenophylla Velen. Fabaceae (AKUH 7613)

Astragalus flavescens Boiss. (AKUH 7618)

Astragalus microcephalus Willd. (AKUH 7615)

Coronilla varia $\mathrm{L}$. subsp. varia (AKUH 7611)

$\begin{array}{lll}\begin{array}{l}\text { Sakızlık otu } \\ \text { Basur otu }\end{array} & \begin{array}{l}\text { Flower } \\ \text { Flower }\end{array} & \begin{array}{l}\text { Digestive disorder } \\ \text { Hemorrhoids }\end{array} \\ \text { Siğilotu } & \text { Flower } & \text { Skin diseases, warts } \\ \text { Mor çiçek } & \text { Flower, Leaf } & \text { Fodder }\end{array}$

Chenopodiaceae Sirken

Sarı sirken

It üzümü

Leaf

Food

Food

Fruit

Food

Kır ıspanağı Leaf Digestive and stomach diseases

Süpürge Branch, Stem Household goods

\section{Tellice $\quad$ Flower Immune system}

Cistaceae $\quad$ Pinar

Leaf, Young

Crafts, coloring, digestive

shoots

Cupressaceae

Gli gli

Leaf, Galbula

Cholesterol, diabetes

Katran ağacı Stem

Kokar ardıcı Leaf

Equisetaceae

Kırk kilit

Stem

Sütleğen

Efek

Eşek geveni

Leaf, Flower

Fodder

Geven

Burçak
Above ground Fodder

parts

Flower, Leaf Respiratory diseases
Infusion as tea.

Flower part is boiled in water in $3-5$ min. It is drunk for hemorrhoidal disease by the use of 10-15 sessions

Infusion as tea.

It is consumed as fresh by animals..

The plant's leaves are boiled, consumed in dough.

The plant's leaves are roasted and the eggs are added on to

Fruits are eaten in fresh

Fried in oil and eaten by shepherds.

Turned into a broom is used as household goods.

Infusion as tea.

The leaves and young branches of the plant are boiled green, yellow and tones are obtained. The leaves and shoots are boiled in water to drink.

The plant's fruit and leaves are boiled in water for 10-15 min for a drink. Fresh fruits are edible or boiled to prepare juice.

The plant body part turned into tar at high temperature and used for cleaning of the infection and digestive problems.

Juniper leaves, broken in and they are applied into the warty zone 30-40 sessions.

Decoction as tea.

The plant is removed from the body in the form of liquid milk. Liquid bread into the stained area and ingested for treatment malaria.

Flowers and fruits are consumed directly.

The plant's leaves and flower parts are consumed directly by animals

Spiny part is burned by shepherds. A hammer or mallet were crushed for animals to eat.

Infusion as tea. 
Table 1 List of plants used as foodstuff or medicinal purposes in Afyonkarahisar (Inner-West Anatolia) (Continued)

Astragalus pisidicus Boiss. \& Heldr. (AKUH 7612)

Quercus ithaburensis Decne. subsp. macrolepis (Kotsch) Hedge\&Yalt. (AKUH 7614)

Quercus cerris L. var. cerris (AKUH 7608)

Quercus infectoria Oliv. subsp. boissieri (Reuter) O.Schwarz (AKUH 7610)

Quercus pubescens Willd. (AKUH 7595)

Hypericum perforatum L. (AKUH 7566)

Hypericum perfoliatum L. (AKUH 7555)

Juglans regia L. (AKUH 7607)

Tymus longicaulis C. Presl subsp. longicaulis var. subisophyllus (Borbas) Jalas (AKUH 7601)

Mentha longifolia (L.) Huds. subsp. typhoides (Briq.) Harley var. typhoides (AKUH 7600)

Teucrium chamaedrys L. subsp. chamaedry. (AKUH 7603)

Origanum vulgare L subsp, hirtum (Link) letsw. (AKUH 7599)

Thymus zygioides Griseb. var. lycaonicus (AKUH 7606)

Salvia cryptantha Montbret \& Aucher ex Bentham (AKUH 7602)

Marrubium globosum Montbret et Aucher ex Bentham (AKUH 7578)

Salvia tomentosa Mill. (AKUH 7579)

Salvia virgata Jacq. (AKUH 7592)

Phlomis armeniaca Willd. (AKUH 7593)

Thymus sipyleus Boiss. subsp. sipyleus

var. sipyleus (AKUH 7604)

Mentha pulegium L. (AKUH 7605)

Teucrium polium L. (AKUH 7591)
Söğüt geveni

Above

\section{parts}

Fagaceae

Palamut

Cup

plant

KIzlmeşe Frut

Fruit

Gerçelik

Fruit eczem

Tüylü meşe

Leaf

Fodder

Hypericaceae

Binbir otu

Above
parts

Binbirdelik otu Leaf, Flower

Digestive system

Juglandaceae

Lamiaceae

Dağ kekiği

Flower

Yabani nane, Leaf

Doğuma

Bodurmamut, Leaf, Flower

sancıotu

Dağ çayı

Flower

Mor kekik

Flower

Kır çayı, şapla

Leaf, Flower

Oğul otu

Karakekik

Leaf

Kır kekiği

Leaf, Flower

Flower

Zorlatma otu Flower

Beyaz kekik Flower

Yarpuz

Flower

$\mathrm{ACl}$ ot

Keten
Infusion as tea.

Cupula of the plant by boiling chickpea yolk color is

obtained for rug weaving.

It is boiled in water and two spoons of juice is consumed on an empty stomach.

Plant crops are exposed as sheep bait.

The leaves of the plant are eaten by animals.

Decoction as tea.

Decoction as tea.

Decoction as tea. It is boiled to obtain dark brown collors and tones for rug weaving.

The plant is consumed in the form of oregano oil. Infusion as tea.

The plant's leaves are consumed in salad Infusion as tea. Dried leaves of the plant are used for spices. Plant leaves are mixed to the dough.

Infusion as tea.

Infusion as tea.

Infusion as tea.

Infusion as tea.

Infusion as tea.

Decoction as tea.

Dried flowers are used for spices by joining tarhana soup

Flower oil is applied to the pain region.

Infusion as tea.

Dried flowers of the herb is consumed as spices. Infusion as

Infusion as tea.

The flowers of the plant are consumed directly.
Respiratory diseases shortness of breath, Refluenza

Hemorrhoids

Food 
Table 1 List of plants used as foodstuff or medicinal purposes in Afyonkarahisar (Inner-West Anatolia) (Continued)

Linum hirsutum L. subsp. anatolicum

(Boiss.) Hayek var. anatolicum.(AKUH

7596)

Viscum album L. subsp. album (AKUH 7594)

Arceuthobium oxycedri (Dc.) M. Bieb. (AKUH 7584)

Malva sylvestris L. (AKUH 7587)

Malva neglecta Wallr. (AKUH 7586)

Morus nigra L.(AKUH 7585)

Peganum harmala L. (AKUH 7572)

Nitrariceae

Üzerlik

Bögem, burç

Leaf, Young

shoots

Ardıç burçu Stem

reliever

\section{Malvaceae}

Ebegümeci

Leaf

Fruit

Üzerlik

Above

parts

Kırlangıç otu Above ground Digestion, hemorrhoids, liver, jaundice, eye parts diseases, skin diseases

Şahtere Flower linfection, fungus

Yaban haşhaşı Leaf Food

Papaver dubium L. (AKUH 7551)

Pinus nigra Arn. subsp. pallasiana

(Lamb.) Holmboe var. pallasiana (AKUH

7565)

Plantago lanceolata L. (AKUH 7525)

Plantago major L. subsp. intermedia

(Gilib.) Lange (AKUH 7531)

Acantholimon ulicinum (Willd. \&

Schultes) Boiss. subsp. lycaonicum

(Boiss. \& Heldr.) Bokhari. \& Edm. (AKUH

7580)

Acantholimon acerosum subsp.

lycaonicum (Willd.) Boiss. var. acerosum (AKUH 7581)

Rumex scutatus L. (AKUH 7569)

Polygonaceae

Household goods, infection, tuberculosis

Rumex patientia L. (AKUH 7571)

Rumex acetosella L. (AKUH 7574)

Rumex crispus L. (AKUH 7575)

Polygonum cognatum Meissn. (AKUH

7518)
Ekşimen Leaf Vitamin needs

Food

Kuzukulağı Leaf

Evelik Leaf

Çobanekmeği
Ilibada, Sabla Leaf
Food

Food

Body resistance
Infusion as tea (1-2 cups a day)

Infusion as tea.

Decoction as tea.

After rosting in oil, it is consumed in the form of food.

Infusion as tea. Fresh leaves of the plant participates in the dough.

Marmalade is made from fruit.

It is believed to prevent for the evil eye to strike the bride and son-in-law.

Infusion as tea. The plant's water is applied to fungal region. The leaves of the plant are consumed by making a salad.

Tar in water is drunk for infection.

Leaf of the plant part is driven directly to the inflamed area. It is used for cleaning of the infection.

Leaf of the plant part affected area to be wrapped, provides to outside infection.

Used in homes as decorative items.

The leaves of the plant are consumed directly. Phyllo dough is made between the rolls. Salad is made. It is consumed directly with salt.

The leaf part is consumed as wheat wrapped (sarma). Leaf of the plant part participates in the dough.

Leaves are eaten directly. Rolls are made, It is eaten.

The leaf part is consumed as wheat wrapped (sarma).

It is eaten as salad. Leaf of the plant part eaten directly. 
Table 1 List of plants used as foodstuff or medicinal purposes in Afyonkarahisar (Inner-West Anatolia) (Continued)

Rumex tuberosus L.subsp. tuberosus L (AKUH 7519)

Portulaca oleraceae L. (AKUH 7522)

Lysimachia vulgaris L. (AKUH 7577)

Nigella sativa L. (AKUH 7559)

Ranunculus ficaria L. subsp. ficariiformis Rouy \& F. (AKUH 7567)

Adonis aestivalis L. subsp. aestivalis L. (AKUH 7516)

Rhamnus rhodopeus Velen. subsp. anatolicus (Grub.) Browicz \& Zieliński (AKUH 7570)

Pyrus elaeagnifolia Pallas subsp. elaeagnifolia Pallas (AKUH 7568)

Rosa hemisphaerica Herrm. (AKUH 7549)

Rosa canina L. (AKUH 7550)

Crataegus monogyna Jacq. subsp. monogyna.(AKUH 7547)

Prunus divaricata Ledeb. subsp. divaricata. (AKUH 7541)

Geum urbanum L. (AKUH 7535)

Crataegus aronia (L.) Bosc. ex DC. (AKUH 7546)

Malus sylvestris Mill. subsp.

orientalis(Uglitzk.) Browicz var. orientalis (AKUH 7540)

Crataegus orientalis Pallas ex M. Bieb.

var. orientalis (AKUH 7544)

Cerasus vulgaris Mill. (AKUH 7539)

Prunus armeniaca L. (AKUH 7533)

Cotoneaster nummularia Fisch. \& C.A.Mey. (AKUH 7536)

Body resistance, vitamin

\section{Portulacaceae Temizlik otu Above ground Food}

Primulaceae Mersin Leaf Digestive diseases

Ranunculaceae Çörek otu Seed

Sarıçiçek, Flower

Düğün çiçeği,

Mayıs çiçeği

Tavukgötü Stem Fodder

Rhamnaceae Yağlıcan çehri, Fruit Karaköken

Rosaceae

Ahlât

Gündöndü

çiçeği

Kuşburnu

Öküzgötü

Fruit

Yabani erik

$$
\text { Fruit }
$$

Dağçayı,

meryemotu

Alı̧

Dağ elması

Fruit

Ahlât

$$
\text { Fruit, Young }
$$$$
\text { shoots }
$$

Yozvişne

Fruit

Kayısı kurusu

Fruit

Muşmula
Respiratory distress, shortness of breath, the immune diseases

Digestion, hemorrhoids, skin diseases

Debilitating, diabetes

Cardiovascular diseases, hypertension

Food

Urea treatment, hemorrhoids, gastric ulcer

Respiratory, cold

Body resistance

Respiratory, influenza

Food

Food

Diabetes, rheumatism

Kidney, diuretic

Digestive and intestinal problems

Food
It is eaten as salad. Leaf of the plant part eaten directly.

The plant's above ground parts especially the leaves part joins into the yogurt. It is eaten as salad.

Infusion as tea (1-2 cups a day)

The plant's seed is consumed directly. Also, it is mixed into the honey.

Infusion as tea (3 cups a day)

The stem of the plant parts are consumed by animals.

Fruits of the plant part eaten directly.

Infusion as tea(4 cups a day) Fruits of the plant part are eaten directly. Designated as a beverage.

Fruits of the plant part eaten directly.

Dried fruit is boiled for a long time in the water to get marmelata. The fruit is boiled and it is taken orally as cold drink. Infusion as tea(3-4 cups a day)

Infusion as tea(2-4 cups a day) Dried fruit is boiled for a long time in the water to get marmelata.

Fruits of the plant part are eaten directly.

Decoction as tea.

Fruits of the plant part are eaten directly.

The fruit of the plant is dried, boiled and drunk as juice.

The ends of the branches and shoots of the plant parts are welded, cold drink. Fruits of the plant part are eaten directly. Infusion as tea(8-10 cups a day) Compote is done from fruits.

Fruits of the plant part are eaten directly. Compote is done from fruits.

Fresh fruits are boiled to prepare jam. Decoction as tea. 
Table 1 List of plants used as foodstuff or medicinal purposes in Afyonkarahisar (Inner-West Anatolia) (Continued)

\begin{tabular}{|c|c|c|c|c|c|}
\hline Salix alba L. (AKUH 7538) & Salicaceae & Söğüt & Leaf & $\begin{array}{l}\text { Painkiller, stomach and respiratory diseases, } \\
\text { shortness of breath }\end{array}$ & Infusion as tea(2 cups a day) \\
\hline $\begin{array}{l}\text { Linaria genistifolia (L.) Mill. subsp. } \\
\text { genistifolia (AKUH 7537) }\end{array}$ & Scrophulariaceae & $\begin{array}{l}\text { Geyşenik, } \\
\text { Meryem otu }\end{array}$ & Flower & Fodder & Animals consume directly. \\
\hline $\begin{array}{l}\text { Linaria genistifolia (L.) Mill. subsp. } \\
\text { confertiflora (AKUH 7517) }\end{array}$ & & $\begin{array}{l}\text { Geyşenik, } \\
\text { Meryem otu }\end{array}$ & Leaf, Flower & Skin disorders, eczema & $\begin{array}{l}\text { Portions of the leaves and flowers are boiled. It is applied 2- } \\
3 \text { times a day for eczema areas. }\end{array}$ \\
\hline Verbascum sp. (AKUH 7527) & & $\begin{array}{l}\text { Öküz kuyruğu, } \\
\text { sığırkuyruğu }\end{array}$ & Leaf, Flower & $\begin{array}{l}\text { Respiratory, asthma, shortness of breath, } \\
\text { skin diseases, warts, eczema }\end{array}$ & $\begin{array}{l}\text { Infusion as tea( } 2-4 \text { cups a day) It is applied } 2-3 \text { times a day } \\
\text { for eczema areas. }\end{array}$ \\
\hline Linaria grandiflora Desf. (AKUH 7529) & & Sarışın & Leaf, Flower & Fodder & Animals consume directly. \\
\hline Urtica dioica L. (AKUH 7526) & Urticaceae & Isırgan & Leaf & Cancer, leukemia & Decoction as tea. \\
\hline Urtica urens L. (AKUH 7530) & & Dağlayan & Leaf & Skin cancer & Decoction as tea. \\
\hline Urtica pilulifera L. (AKUH 7524) & & Isırgan otu & Leaf & Food & Decoction as tea. \\
\hline Tribulus terrestris L. (AKUH 7523) & Zygophyllaceae & $\begin{array}{l}\text { Çoban } \\
\text { çökerten }\end{array}$ & $\begin{array}{l}\text { Flower, Leaf, } \\
\text { Root }\end{array}$ & Kidney sand, hemorrhoids & $\begin{array}{l}\text { Leaves are consumed to make taco. The flower oil is applied } \\
\text { for hemorrhoids. }\end{array}$ \\
\hline
\end{tabular}




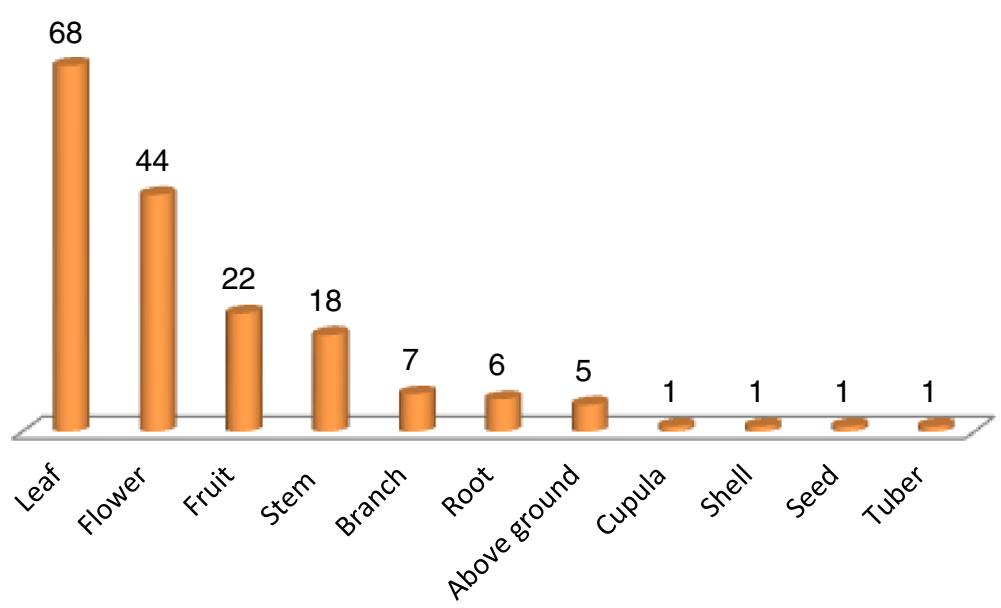

Fig. 2 Used parts of the medicinal plants and their usage frequencies in the study area

When the 130 taxa's usage types are analyzed, it can be seen that the most frequently used parts were leaves (68), flowering branches and flowers (44), fruits (22) and stem (18) (Fig. 2). The usage frequencies of plant parts are observed to be different from local to local $[5,7,30,35,38,41]$.

Medicinal use occupies the first place among 178 types of use with 84 remedies. The province of İzmir, Denizli, Ankara, Bilecik, Balıkesir, Muğla are close to our study area. The results of analysis showed that the percentage of the uses shows some similarities. The medicinal plants $(47.2 \%)$ are the most cited in Afyonkarahisar. This is almost in agreement with former studies by Ertuğ et al. [7] in Buldan (Denizli) with $42 \%$, Ertuğ [41] in Muğla with $43 \%$, Şimşek et al. [5] with $60 \%$ in Ankara, Ugulu et al. [35] with $67 \%$ in Izmir and Güler et al. [30] with $58 \%$ in Bozüyük (Bilecik). These results revealed that local people prefer widely to use the plants for medicinal purposes. The reasons for using the plants widely could be economic, because reaching them easily in folk bazaars and actars with a small amount of money. On the other hand, cultural aspects also play an importan role to use the plants for medicinal purposes.

The rate of food, fodder, others (household goods, dyes, handicrafts and religious) are 38.2, 9 and $5.6 \%$, respectively. The rates are similar with the studies of Ertuğ [41] in Muğla (38, 15, 5 \%) and Şimşek et al. [5] in Ankara (36 \%, others $(4 \%)$ ). According to the data obtained from field work field, plants used by people for infection (10\%), respiration $(9 \%)$, stomachache $(8 \%)$, skin diseases, wart, eczema (7 \%), digestion (7\%), hemorrhoids (6\%), painkiller (5\%), body resistance (4\%), blood sugar regulator (3\%), and other diseases (41 \%) (Fig. 3, Table 1). Polat \& Satıl [38] reported that various diseases are gastro-intestinal disorders, respiratory and throat diseases, diabetes, kidney ailments, healing cut and wounds, hemorrhoids, anorexia

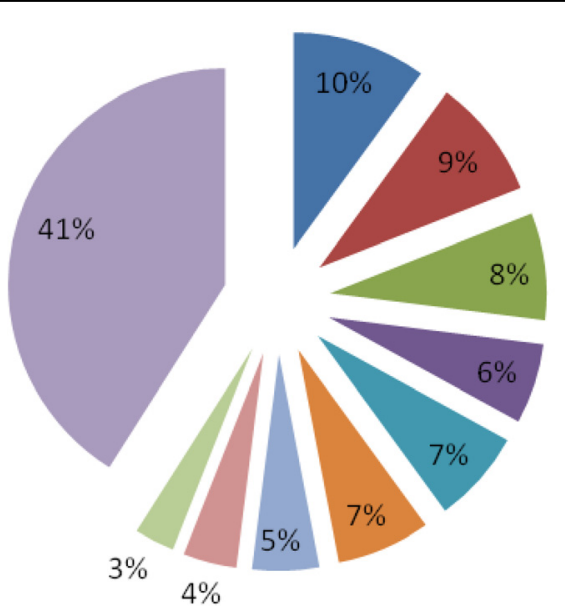

- Infection

- Respiratory diseases

- Stomach

- Hemorrhoids

n Skin diseases, Warts, Eczema

Digestive diseases

Painkillers

Body resistance

nugar setter

n Diğer

Fig. 3 The use aim and usage percentages of the plants in the study area 
and hypertension stabilizer in Edremit Gulf (Balıkesir). This shows us that the priority of people in using medicinal plants in different localities is different to treat ailments.

We have seen that the culture and ethnobotanical informations that people have gained with centuries of traditional methods are disappearing. Especially today, we can say that increasing of purchasing power and the wealth level has led to a decrease in the use of plants, with more people buying convenience foods, to use cultivated plants, and supplying their medication needs by buying pharmaceuticals from a pharmacy. We determined that in areas where purchasing power is low, people are more prone to ethnobotanical culture.

Particularly, the facts that there are no pharmacies in villages and towns, economic power is low, increased contact with plants, and success in solving some medicinal problems with culture they gained over generations promoting ethnobotanical culture. In comparison to some studies conducted in near areas (in Anatolia), there are some differences in local naming, purpose of use, and how to use plants.

While Agrostemma githago "Sakızlık otu" is used in medicinal purposes especially in digestive and alvine conditions in the study region. It is used as ornament along with medicinal purposes [23]. We saw that the plant Amaranthus retroflexus was used both as food and for medicinal purposes, especially to treat conditions such as influenza or cold [23]. It was also observed that the plant is called different names such as "Paşa pancarı" and "Kızılbacak" in different localities. Bellis perennis, which is called as "Çayır papatyası", is used for medicinal purposes to treat respiratory diseases. It is also used for cold and flu, stomach-ache, strengthen hair [19]. It is noted that Capsella bursa-pastoris "Coban çantası" is consumed as food by informants, it is also used as food and fodder [1], as food, medicine, fodder and other [23] and as food and medicine [50]. People eat it in meal, roast, soup, or salads [11], cooked as meal with rice and eaten with garlicyogurt [22]. We note that the purpose of use as food is common in the compared studies.

Cerinthe minor subsp. auriculata is given to the animals as fodder; people are also reported to use it as food in times of famine [1]. Chelidonium majus, called "Kırlangıç otu", is used especially as food and medicine by locals, and it is reported that it benefits conditions related to liver and hemorrhoids. Previous study showed that Chelidonium majus is used to treat wart [23]. In some regions, its medicinal uses and purposes differ.

It was reported that Dianthus zonatus was used to treat wart by the studies $[1,23,50]$ as we found the same purpose. On the other hand, Ficus carica L. is used to treat wart in Bozüyük (Bilecik-Turkey) [30]. Dracunculus vulgaris is called "Deli otu" and is used for infections, and the same aim was reported in the previous studies
$[1,23,50]$. It is called as "Yllan bırcağı, köpeksiyen" in Edremit (Balıkesir-Turkey) and used for hemorrhoids, carminative (for animal) [38]. Hypericum perforatum shows the same usage as painkiller in the study region and this was repoted in the previous studies $[1,23,50]$. It is also used for stomachache by the report of Güler et al. [30]. While Portulaca oleracea, "temizlik otu", is greatly consumed as food in Afyonkarahisar, it is used as salad, pickle and jam in Mersin and Adana provinces (Turkey) [18]. Urtica dioica, called "Isirgan", is used to treat cancer and leukemia by informants. In the other studies, it is used for medicinal purposes $[1,23,50]$ and for dye [20, 27]. The plant Vaccaria pyramidata var. grandiflora is used as fodder in the study region.

Sample survey of some plants is conducted according to compared data. We can come to the conclusion that both local names and uasege purposes of the plants are either the same or vary sometimes. People's frequency of contact with plants, relation status, passing the plant to next generation, means, and environmental conditions may cause this variety. When we compared some of the plants with some studies in Turkey and in the other countries, we found some differences. While Anchusa azurea var. azurea is used to treat stomachache, vulnerary, and female sterility as reported in other region [51, 52], we found that it is used as food in the study region. Capsella bursa-pastoris is used as an astringent; in burn wound care, for constipation and intestinal spasm, as a diuretic, a hemostatic, and for intestines, kidney swelling, rheumatism, and urinary disorders [23, 53-55], we report that it is used as food. Peganum harmala is used for the eliminating the evil eye in our study and used as an analgesic, to treat epilepsy and headache [56], rheumatic pain [44]. Papaver dubium is used to treat cold [57], while it is used as food and sedative in our study. Mentha longifolia is used to treat halitosis, constipation, common cold, fever, and general weakness and is antispasmodic [58, 59], while it is used to treat Vitamin C deficiency in this study. Morus alba is used to treat cancer in our study, while it is used to treat anemia, blood forming, dizziness, hepatitis, incontinence, insomnia, and palpitations in other locals [40,60]. Plantago major is reported to be used by wrapping its leaf around wounded area causing suppuration to flow out. In other studies, it is used to treat, cicatrizer, constipation, hemorrhoids, and wounds [58, 61]. While Tribulus terrestris is used to treat athlete's foot, eczema, kidney and gallstones, hemorrhoids, and warts [38,62], our study showed that its leaves are consumed by forming wraps. Local people also drink its oil, and it is reported to benefit kidney gravel. The oil of the plant is applied to area affected by hemorrhoids.

Salix alba is reported to be used to treat athlete's foot and vaginal itching [23], we found that it is used to treat pain, stomachache, and respiratory conditions in this study. Urtica dioica is used to treat asthma, blood sugar, 
and intestinal pains, and is used as a diuretic, galactagogue, and post-partum depurative [63, 64] while it is used to treat cancer and leukemia in our study. Crataegus monogyna is used to treat respiratory conditions and cold while it is also used to treat arythmia, cardiotonic, diabetes, and is a vasodilator [23].

The majority of the Origanum vulgare, Thymus spp., $H y$ pericum perforatum, Achillea millefolium, Rosa canina, Melissa officinalis, Mentha longifolia etc. species are well known in European folk medicine for their digestive properties, which is also one of the reasons cited for the selection of plants for teas to accompany meals $[65,66]$. In the Russian study area, the most used medicinal herbs are $\mathrm{Hy}$ pericum perforatum and Plantago major. The Russian respondents considered it important to use medicinal herbs during winter times to prevent flu and common colds [67]. Amaranthus spp. [68, 69], Arum elongatum and Lactuca spp. [70], Atriplex sp. [71, 72], Malva neglecta [73], Malva sylvestris [70, 74], Morus nigra, Onopordum anatolicum [70, 75], Plantago major [76], Rumex patientia, Sinapis arvensis [1, 11, 70-80], Salvia spp., Beta trigyna [81, 82], Urtica dioica [83], the leaves of taxa are used for preparing food (sarma = stuffed food etc.) in the folk cuisines of Turkey and the Balkans. In our study we observed that Peganum harmala' burn incense is believed in to bring about good deed. In the wedding day, the bride and groom are being incensed to get rid off the evil's harm. It is used in Pakistan for emotional disturbances, painful menstruation, seizures, insanity and itchy skin. Abdominal pain and smoke has insecticidal properties [84].

Pinus nigra in Anatolia (spoon making, animal fodder, wetland making), Cedrus libani (bowl and spoon making), Salix alba (basket weaving), Juglans regia (dyes), Quercus infectoria (dyes) are used for different purposes [85].

The local names and common families and some species were shared in Anatolia and central Asia (Uzbekistan) [18, 86, 87]. For example, yarpuz/nane for Mentha sp., Qoratut/dut for Morus sp., itburnu/kuş burnu for Rosa sp. (Tablo 1) [87]. In this case, it is a sign that the culture of Anatolia common with central Asia as coming the roots from there.

\section{Conclusions}

This study documented and analyzed traditional ethnobotanical knowledge and 178 different remedies of 130 taxa belonging to 39 families. The results of this study indicated that the local community of the study area used the plants as medicinal (84) and food (68) fodder (16), household goods (3), dyes (3), handicrafts (3) and religious (1). The most common cited usages of plants are still folk medicine and food. Because villagers are generally migrating to big cities and benefiting from the facilities of modern medicine, the heritage of traditional ethnobotanical knowledges is decreasing dramatically. Although this relieve some of the pressures on some plant species, documenting and analizing the indigenous wild plants' ethnobotanical usages through ethnobotanical studies is still important for the conservation of traditional ethnobotanical knowledge.

\section{Competing interests}

The authors declare that they have no competing interests.

\section{Authors' contributions}

SA, main author, involved in the study design, conducting of interview, field work, literature Review and general data collection and systematization. MT wrote the first draft, and $\mathrm{MK}^{2}$ wrote $\mathrm{ms}$, designed figures, references and participated in fieldwork. MK ${ }^{1}$ diagnosed the plants, and participated in fieldwork. All authors read and approved the final manuscript.

\section{Acknowledgement}

We express our thanks to The Coordination Unit of Scientific Research Projects at Afyonkarahisar Kocatepe University for financial support. We would like to thank local communities for sharing their knowledge and experiences. Our special thanks also to Dr H Shazly (Swansea-UK) due to checking its English.

\section{Author details}

${ }^{1}$ Department of Molecular Biology and Genetics, Science \& Arts Faculty, Afyon Kocatepe University, 03200 Afyonkarahisar, Turkey. ${ }^{2}$ Department of Molecular Biology and Genetics, Faculty of Engineering and Natural Sciences, Üsküdar University, 34662 Istanbul, Turkey.

Received: 11 April 2015 Accepted: 30 October 2015

Published online: 23 December 2015

\section{References}

1. Vural G. Ethnobotanical features some of the wild plants on the Honaz mountain and its environment, MSc thesis. Afyonkarahisar: Afyon Kocatepe University; Department of Biology; 2008

2. Cotton CM. Ethnobotany principles and applications. Chichester: John Wliley \& Sons; 1996. 424 pp.

3. Harsha VH, Hebbar SS, Hegde GR, Shripathi V. Ethnomedical knowledge of plants used by Kunabi tribe of Karnataka in India. Fitoterapia. 2002;73:281-7.

4. Randriamiharisoa MN, Kuhlman AR, Jeannoda V, Rabarison $H$, Rakotoarivelo $\mathrm{N}$, Randrianarivony $\mathrm{T}$, et al. Medicinal plants sold in the markets of Antananarivo. Madagascar J Ethnobiol Ethnomed. 2015;11:60.

5. Uğulu İ, Başlar S, Yörek N, Doğan Y. The investigation and quantitative ethnobotanical evaluation of medicinal plants used around Izmir province, Turkey. J Med Plant Res. 2009;3(5):345-367.

6. De Natale A, Pollio A. Plants species in the folk medicine of Montecorvino Rovella (Inland Campania, Italy). J Ethnopharmacol. 2007;109:295-303.

7. Ertuğ F, Tümen G, Çelik A, Dirmenci T. Ethnobotanical survey of Buldan (Denizli), 2003. TUBA Culture Inventory. 2004;2:187-218.

8. Tahraoui A, El-Hilaly J, Israili ZH, Lyoussi B. Ethnopharmacological survey of plants used in the traditional treatment of hypertension and diabetes in SouthEastern Morocco (Errachidia Province). J Ethnopharmacol. 2006;110:105-17.

9. Teklehaymanot T, Giday M, Mehdim G, Yalemtsehay M. Knowledge and use of medicinal plants by people around Debre Libanos Monastery in Ethiopia. J Ethnopharmacol. 2007;111:271-83.

10. Güner A, Ozhatay N, Ekim T, Baser KHC. Flora of Turkey and the East Aegean Islands. Edinburgh: Edinburgh University Press; 2000.

11. Dogan Y. Traditionally used wild edible greens in the Aegean Region of Turkey. Acta Soc Bot Pol. 2012;81(4):329-42.

12. Inan E, İpek G, İpek A. Endemic medicinal plants of Çankırı. J Turkish Sci. 2012;5:38-40.

13. Tabata M, Sezik E, Honda G, Yeşilada E, Fukui H, Goto K, et al. Traditional medicine in turkey III: folkmedicine in east Anatolia, Van and Bitlis provinces. Int J Pharm. 1994:32:3-12. 
14. Yeşilada E, Honda G, Sezik E, Tabata M, Fujita T, Tanaka T, et al. Traditional medicine in Turkey V. Folk medicine in the inner Taurus Mountains. J Ethnopharmacol. 1995:46:133-52.

15. Baytop T. Therapy with medicinal plants in Turkey (past and present). 2nd ed. Istanbul: Nobel Medicine Publication; 1999. p. 118-9.

16. Tuzlacı E, Erol MK. Turkish folk medicinal plants, Part II. Eğirdir (Isparta). Fitoterapia. 1999;70:593-610.

17. Yeşilada E, Sezik E, Honda G, Takaishi Y, Takeda Y, Tanaka T. Traditional medicine in Turkey IX. Folk medicine in north-west Anatolia. J Ethnopharmacol. 1999:64:195-210.

18. Everest A, Ozturk E. Focusing on the ethnobotanical uses of plants in Mersin and Adana provinces (Turkey). J Ethnobiol Ethnomed. 2005;1:6

19. Hayta S, Polat R, Selvi S. Traditional uses of medicinal plants in Elazığ (Turkey). J Ethnopharmacol. 2014;154:613-23.

20. Doğan Y, Başlar S, Mert HH, Ay G. Plants used as natural dye sources in Turkey. Econ Bot. 2003;57(4):442-53.

21. Sezik E, Yeşilada E, Honda G, Takaishi Y, Takeda Y, Tanaka T. Traditional medicine in Turkey X. Folk medicine in Central Anatolia. J Ethnopharmacol. 2001;75:95-115.

22. Simsek I, Aytekin F, Yesilada E, Yildirimli ş. An ethnobotanical survey of the Beypazarı, Ayaș, and Güdül District Towns of Ankara province (Turkey). Economic Bot. 2004;58:705-20.

23. Sargın SA, Akçicek E, Selvi S. An ethnobotanical study of medicinal plants used by the local people of Alaşehir (Manisa) in Turkey. J Ethnopharmacol. 2013;150:860-74.

24. Tuzlacı E, Aymaz PE. Turkish folk medicinal plants, Part IV: Gönen (Balıkesir) Fitoterapia. 2001;72:323-43.

25. Öztürk F, Ölçücü C. Ethnobotanical features of some plants in the district of Şemdinli (Hakkari-Turkey). Int J Acad Res. 2011;3:120-5.

26. Malyer H, Özaydın S, Tümen G, Er S. Ethnobotanics characteristics of plants sold in herbalist in Tekirdağ and its surroundings. Dumlupınar Univ J Sci. 2004;7:103-11.

27. Özgökçe F, Özçelik H. Ethnobotanical aspects of some taxa in East Anatolia (Turkey). Econ Bot. 2004:58:97-704.

28. Elçi B, Erik S. Ethnobotanical properties of Güdül (Ankara) and near environs. Hacettepe Univ J Pharmacy. 2006:25:57-64.

29. Ezer N, Arısan ÖM. Folk medicines in Merzifon (Amasya, Turkey). T J Bot. 2006:30:223-30.

30. Güler B, Manav E, Uğurlu E. Medicinal plants used by traditional healers in Bozüyük (Bilecik-Turkey). J Ethnopharmacol. 2015;173:39-47.

31. Akan H, Korkut MM, Balos MM. An ethnobotanical study around Arat Mountain and its surroundings (Birecik, Sanlıurfa). Fırat Univ J Sci and Eng. 2008;20:67-81

32. Satıl F, Akçiçek $E$, Selvi S. An ethnobotanicaly study in Madra Mountain (Balıkesir-Izmir) and vicinity. Research J Biol Sci. 2008;1:31-6.

33. Koyuncu O, Yaylacı ÖK, Tokur S. A study on Geyve (Sakarya) and its environs in terms of ethnobotanical aspects. Herb J Syst Bot. 2009;16:123-42.

34. Sarper F, Akaydın G, Şimşek I, Yeşilada E. An ethnobotanical field survey in the Haymana district of Ankara province in Turkey. T J Biol. 2009;33:79-88.

35. Ugulu I, Baslar S, Yorek N, Dogan Y. The investigation and quantitative ethnobotanical evaluation of medicinal plants used around Izmir province Turkey J Med Plants Res. 2009:3:345-67.

36. Tuzlacı E, İşbilen DFA, Bulut G. Turkish folk medicinal plants, VIII: Lalapaşa (Edirne). J Marmara Pharm. 2010;14:47-52.

37. Uysal I, Onar S, Karabacak E, Çelik S. Ethnobotanical aspects of Kapıdağ Peninsula (Turkey). Bio Di Con. 2010;3:15-22.

38. Polat R, Satıl F. An ethnobotanical survey of medicinal plants in Edremit Gulf (Balıkesir-Turkey). J Ethnopharmacol. 2011;139:626-41.

39. Demirci S, Özhatay N. An ethnobotanical study in Kahramanmaraş (Turkey): wild plants used for medicinal purpose in Andırın. Kahramanmaraş T J Pharm Sci. 2012:9:75-92.

40. Sağıroğlu M, Arslantürk A, Akdemir ZK, Turna M. An ethnobotanical survey from Hayrat (Trabzon) and Kalkandere (Rize/Turkey). Bio Di Con. 2012:5:31-43.

41. Ertuğ F. Wild edible plants of the Bodrum area (Muğla, Turkey). Turk J Bot. 2004;28:161-74.

42. Honda G, Yeşilada E, Tabata M, Sezik E, Fujita T, Takeda Y, et al. Traditional medicine in Turkey VI. Folk medicine in West Anatolia: Afyon, Kütahya, Denizli, Muğla, Aydın provinces. J Ethnopharmacol. 1996;53:75-87.

43. Akçiçek $E$, Vural M. Indegenous names and ethnobotanical properties of Kumalar mountain (Afyon) and its vicinity. Herb J Syst Bot. 2003;10(2):151-62.
44. Kargıoğlu M, Cenkci S, Serteser A, Evliyaoğlu N, Konuk M, Kök MŞ, et al. An ethnobotanical survey of interior-west Anatolia. Turkey Hum Ecol. 2008;36:763-77.

45. Kargıoğlu M, Cenkci S, Serteser A, Konuk M, Vural G. Traditional Uses of Wild Plants in the Middle Aegean Region of Turkey. Hum Ecol. 2010;38:429-50.

46. Arı S, Kargıoğlu M, Temel M, Konuk $M$. Traditional tar production from the Anatolian black pine [Pinus nigra Arn. subsp. pallasiana (Lamb.) Holmboe var. pallasiana] and its usages in Afyonkarahisar, Central Western Turkey. J Ethnobiol Ethnomed. 2014;10:1-9.

47. Acar H. Gypsium soils and vegetation relations in Afyonkarahisar. MSc thesis. Afyonkarahisar: Afyon Kocatepe University, Department of Biology; 2012.

48. Erinç S. Klimatoloji ve Metotları. İstanbul: I.T.Ü. Deniz Bilimleri ve Coğrafya Enstitüsü; 1984.

49. Davis PH. Flora of Turkey and the East Aegean Islands. Edinburgh: Edinburgh University Press; 1988 (Vol 1-10).

50. Alpaslan Z. The ethnobotanical properties of Ergan Mountain (Erzincan), MSc thesis. Erzincan: Erzincan University, Department of Biology; 2012

51. Altundag E, Ozturk M. Ethnomedicinal studies on the plant resources of east Anatolia, Turkey. Proced Soc Behav Sci. 2011;19:756-77.

52. Cakilcioglu U, Civelek $\$$. Flora of the region between Coper Mine and Tekevler Village (Maden-Elazığ). Bio Di Con. 2011;4:54-66.

53. Macia MJ, Garcia E, Vidaurre PJ. An ethnobotanical survey of medicinal plants commercialized in the markets of La Pazand El Alto. Bolivia J Ethnopharmacol. 2005:97:337-50.

54. Aburjai T, Hudaib M, Tayyem R, Yousef M, Qishawi M. Ethnopharmacological survey of medicinal herbs in Jordan, the Ajloun Heights Region. J Ethnopharmacol. 2007:110:294-304.

55. Leto C, Tuttolomondo T, La Bella S, Licata M. Ethnobotanical study in the Madonie Regional Park (Central Sicily, Italy). Medicinal use of wild shrub and herbaceous plant species. J Ethnopharmacol. 2013;146:90-112.

56. Eissa TAF, Palomino OM, Carretero ME, Gómez-Serranillos MP. Ethnopharmacological study of medicinal plants use disorders in Sinai Peninsula. Egypt J Ethnopharmacol. 2014;151:317-32.

57. Çakılcıoğlu U, Şengün MT, Türkoğlu I. An ethnobotanical survey of medicinal plants of Yazıkonak and Yurtbaşı Districts of Elazı̆̆ Province. Turkey J Med Plants Res. 2010:4:567-72.

58. Çakılcıoğlu U, Khatun S, Turkoğlu I, Hayta S. Ethnopharmacological survey of medicinal plants in Maden (Elazığ-Turkey). J Ethnopharmacol. 2011;137:469-86.

59. Durmuşkahya C, Öztürk M. Ethnobotanical survey of medicinal plants used for the treatment of diabetes in Manisa. Turkey Sains Malaysiana. 2013;42:1431-8

60. Mathur A, Joshi H. Ethnobotanical studies of the Tarai region of Kumaun, Uttarakhand. India Ethnobot Res Appl. 2013;11:175-203.

61. Di Novella R, Di Novella N, De Martino L, Mancini E, De Feo V. Traditional plant use in the national park of Cilento and Vallo Di Diano, Campania Southern. Italy J Ethnopharmacol. 2013;145:328-42.

62. Said O, Khalil K, Fulder S, Azaizeh H. Ethnopharmacological survey of medicinal herbs in Israel, the Golan Heightsand the west Bankregion. J Ethnopharmacol. 2002;83:251-65.

63. Ghorbani A. Studies on pharmaceutical ethnobotany in the region of Turkmen Sahra, north of Iran (part 1): general results. J Ethnopharmacol. 2005:102:58-68.

64. Pieroni A, Quave CL. Traditional pharmacopoeias and medicines among Albanians and Italians in Southern Italy: a comparison. J Ethnopharmacol. 2005;101:258-70.

65. Pardo-de-Santayana M, Blanco E, Morales R. Plants known as "té" (tea) in Spain. An ethno-pharmaco-botanical review. J Ethnopharmacol. 2005:98:1-19.

66. Sõukand R, Kalle R. The use of teetaimed in Estonia, 1880s-1990s. Appetite. 2012:59:523-30

67. Stryamets N, Elbakidze M, Ceuterick M, Angelstam P, Axelsson R. From economic survival to recreation: Contemporary uses of wild food and medicine in rural Sweden, Ukraine and NW Russia. J Ethnobiol and Ethnomed. 2015:11:53.

68. Baytop T. Turkish dictionary of plant names. Ankara: Türk Dil Kurumu Yayınlarl; 2007

69. Güneş S. Ethnobotanical investigation on the use of plants in the villages of Karaisali (Adana), MSc thesis. Niğde: Niğde University; Department of Biology; 2010

70. Dogan Y, Baslar S, Ay G, Mert HH. The use of wild edible plants in western and central Anatolia (Turkey). Econ Bot. 2004;58(4):684-90. 
71. Nedelcheva A. An ethnobotanical study of wild edible plants in Bulgaria. Eurasia J Bio Sci. 2013;7:77-94.

72. Markova M. Hrana i hranene. Mezhdu priroda i kultura [food and nutrition: between nature and culture]. Sofia: Profesor Marin Drinov Academic Publishing House; 2011.

73. Mükemre M. Ethnobotanical features of Konalga, Sırmalı, Dokuzdam Villages (ÇatakNan) and their vicinity, MSc thesis. Van: Yüzüncü Yıl University; Department of Biology; 2013.

74. Emre Bulut G. Ethnobotanical investigations in Bayramiç (Çanakkale), MSc thesis. Istanbul: Marmara University; Department of Pharmaceutical Botany; 2008.

75. Gürdal B, Kültür \$̧. An ethnobotanical study of medicinal plants in Marmaris (Muğla, Turkey). J Ethnopharmacol. 2013;146:113-26.

76. Pieroni A, Rexhepi B, Nedelcheva A, Mustafa B, Hajdari A, Kolosova V, et al. One century later: The folk botanical knowledge of the last remaining Albanians of the upper Reka Valley, Mount Korab. Western Macedonia J Ethnobiol Ethnomed. 2013;9:22

77. Dogan Y, Ugulu I, Durkan N. Wild edible plants sold in the local markets of İmir. Turkey Pak J Bot. 2013;45:177-84.

78. Yücel E, Güney F, Yücel SLL. The wild plants consumed as a food in Mihalıç̧̧ık district (Eskişehir/Turkey) and consumption forms of these plants. Bio Di Con. 2010;3(3):158-75.

79. Simşek I, Aytekin F, Yesilada E, Yıldırımlı S. An ethnobotanical study among the population on the purpose of plant utilization in Anatolia. In: Başer KHC, Kırımer N, editors. 14. Herbal Pharmaceutical Raw Materials Conference Proceedings. Eskişehir: Eskisehir Anadolu University; 2002. p. 434-57.

80. Poyraz Kayabașı N. The ethnobotanical examine in the villages of Manyas and Manyas, MSc thesis. Balıkesir: Balıkesir University; Department of Biology; 2011.

81. Kaval I. The ethnobotany of Geçitli (Hakkari) and its vicinity, MSc thesis. Van: Yüzüncü Yıl University; Department of Biology; 2011.

82. Aras N. 'Sarma' and 'Dolma': Rolled and stuffed dishes as therapy tools for the Anatolian women in the kitchen. In: Mc Williams M, editor. Wrapped and stuffed foods. Proceedings of the Oxford symposium on food and cookery 2012. Totnes: Prospect Book; 2013. p. 57-67.

83. Balos MM. The flora and ethnobotany of the region between Zeytinbahçe and Akarçay (Birecik), MSc thesis. Şanlıurfa: Harran University; Department of Biology; 2007

84. Sultana S, Khan MA, Ahmed M, Zafar M. Indigenous knowledge of folk herbal medicine by the women of district Chakwal Pakistan. Int Web J Ethnobot Leaflets. 2006;10:243-53.

85. Polat R, Satı F. Ethnobotanical investigations in Havran and Burhaniye (Balıkesir). J TUBA Culture Inventory. 2010;8:65-100.

86. Bingöl F. Some drug samples sold in the herbal markets of Ankara. Herb J Syst Bot. 1995;2(2):83-110.

87. Sezik E, Yesilada E, Shadidoyatov H, Kuliyev Z, Nigmatullaev AM, Aripov HN, et al. Folk medicine in Uzbekistan. I. Toshkent, Djizzax, and Samarqand provinces. J Ethnopharmacol. 2004;92:197-207.

\section{Submit your next manuscript to BioMed Central and take full advantage of:}

- Convenient online submission

- Thorough peer review

- No space constraints or color figure charges

- Immediate publication on acceptance

- Inclusion in PubMed, CAS, Scopus and Google Scholar

- Research which is freely available for redistribution 